\title{
Эволюция детерминант универсального дизайна в условиях новых вызовов современного мира
}

\author{
Константин Зборовский${ }^{1}$, Наталья Лазовская ${ }^{2}$
}

\section{АННОТАЦИЯ}

Статья посвящена концептуальным вопросам изменения детерминант универсального дизайна под влиянием пандемии и, соответственно, других возможных вызовов современному человечеству, сконцентрированному в урбанистических условиях проживания. Авторы рассматривают альтернативные тенденции в организации жилой среды и жизнедеятельности человека, позволяющие нивелировать риски, определяемые современными вызовами цивилизации, а также создание условий для обеспечения полного физического, психического и социального благополучия человека.

\section{КЛЮЧЕВЫЕ СЛОВА:}

jakość przestrzeni architektonicznej; materiały i technologie budowlane

\section{1. Введение}

Трансформация среды проживания человека происходила практически на всех этапах эволюции. Катализаторами тех или иных тенденций являлись как в целом векторы научно- технического прогресса, так и развитие промышленности, и связанные с ним соответствующие изменения социально-средовой инфраструктуры. Безусловно, эволюционный процесс имеет линейную структуру при рассмотрении его в глобальном историческом аспекте, но необходимо заметить, что в более коротких исторических периодах всегда выделялись ступени, которые подталкивали или перенаправляли эволюционные процессы под воздействием определенных экологических, социальных вызовов конкретного времени.

Таким образом, на долю практически каждого поколения выпадали триггеры, определявшие и корректировавшие направления и принципы организации среды жизнедеятельности человека. Так, например, быстрое развитие промышленности стимулировало урбанистические тенденции и аграрные общества трансформировались в урбанистические, что в свою очередь вело к значительным потребностям изменения как социальной, так и средовой инфраструктуры. Человечество затянуло себя в абсолютную зависимость от функционирования глобальных организационных систем и, соответственно, поставило устойчивость и безопасность жизнедеятельности человека в зависимость от дееспособности коммунальной и социальной инфраструктуры его социально-средового окружения.

Последние два года человечество столкнулось с очередным глобальным вызовом пандемией COVID-19, к которому оказалось абсолютно не готово. Пандемия стала детона-

${ }^{1}$ Белорусский государственный университет физкультуры, кафедра «Спортивная медицина», Республика Беларусь, г. Минск, пр. Победителей 104, e-mail: zbarouski@mail.ru, orcid id: 0000-0003-2712-1358

2 Белорусский национальный технический университет, кафедра «Архитектура жилых и общественных зданий»,

Республика Беларусь, Минск, пр. Независимости, 65, e-mail: nat-lazovskaya@yandex.ru, orcid id: 0000-0002-2412-7278 
тором, запустившим процессы осознания человечеством уровня собственной уязвимости и, подтолкнувшим к переосмыслению как общечеловеческих ценностей и жизненных принципов, так и направления дальнейшего социального, средового, инфраструктурного развития, главной детерминантой которого стала устойчивость, коллективная и индивидуальная безопасность, что в свою очередь определено чувством сохранения как популяции, так и биологического вида в целом.

Настоящая публикация базируется как на научном анализе авторами современных тенденций, так и на собственном эксперименте в рамках первичной социальной ячейки, позволившем полноценно стабилизировать и вернуть на прежний уровень все социальные роли респондентов.

\section{2. Эволюция концепции организации жизнедеятельности человека в условиях новых вызовов современности}

Современные тенденции в развитии универсального дизайна на протяжении последних лет шли в направлении создания комфортных дружественных условий для жизнедеятельности и максимальной социальной активности различных групп населения, нивелируя вокруг них всевозможные барьеры, возникающие вследствие особенностей развития человека, либо его инвалидности, изменения возрастного ценза, изменения социального статуса, например, появления в семье маленьких детей, либо попадания человека в условия одиночества и т.д. Данные тенденции заслуживают абсолютной поддержки и одобрения, но на современном этапе требуют внесения корректив как на уровне понимания, так и на различных технологически реализационных уровнях [1].

В период пандемии люди столкнулись с необходимостью организации жизнедеятельности в условиях локдаунов с ограничением жизненных пространств до уровня жилых ячеек, резкого сокращения естественных социальных контактов с переходом на общение в виртуальной среде как по вопросам реализации профессиональных и образовательных задач, так и повседневного межличностного общения. Данные обстоятельства показали явный диссонанс в психологической устойчивости и изменении параметров психического здоровья в различных группах населения, степень которых, безусловно, зависела от психотипа человека, степени его интро- или экстравертности. Гиподинамия - второй серьезный момент, заслуживающий внимания. Третий момент - это сокращение возможностей получения поддержки и помощи в социальных, в т. ч. медицинских учреждениях, из-за высокого риска заразиться. Четвертый момент - это неготовность людей самостоятельно справляться с насущными жизненными проблемами или значительное ограничение. Например, в группах пожилых людей отмена привычных мероприятий, определявших на протяжении многих лет их социальную включенность, помощь и поддержку. Данный перечень можно перечислять и далее, но обобщая структуру изменений жизнедеятельности и всевозможных рисков мы видим, что на поверхность всплывает практически весь спектр факторов риска неинфекционных (сердечно-сосудистых, эндокринных, психических и др.) заболеваний, определявших в последние десятилетия основную заболеваемость и смертность населения.

Данные обстоятельства четко указывают на необходимость поиска более приемлемых с точки зрения эпидемической и социальной безопасности форм организации жизнедеятельности человека.

В США и европейских странах во второй половине 2020 года резко повысился спрос на жилье вне пределов мегаполисов. Работа и учеба в удаленном формате снизили фактор локации жилых домов в пользу уменьшения плотности застройки, минимизации транспортного перемещения, увеличения социального дистанцирования и отсутствия вынужденных контактов с целью уменьшения распространения коронавирусной инфекции. 


\section{3. Тенденции организации жилой среды в Республике Беларусь в условиях пандемии}

Концентрация населения в столице Республики Беларусь г. Минске, в областных центрах - Бресте, Витебске, Гомеле, Гродно, Могилеве, а также в городах с населением свыше 100 тыс. человек (Барановичи, Борисов, Пинск и др.) - характерный показатель для страны. В крупных городах с численностью населения свыше 100 тыс. человек проживает порядка $70 \%$ всего городского населения и только около $30 \%$ в малых и средних городах, в то время как малые и средние города составляют $90 \%$ от общего числа городов Беларуси. Численность городского населения в 2018 году составила 78,09\% (при этом увеличение численности городского населения происходило за счет миграции из сельской местности), в то время как численность сельского населения - всего 21,91\% [1].

C началом пандемии COVID-19 в 2020 году наблюдается тенденция дезурбанизации и миграции населения из крупных городов в малые и средние, в сельскую местность, в пригороды и дачные поселки.

Наиболее востребованными оказались такие форматы жилья как таунхаусы, лайнхаусы, урбан виллы, малоэтажные индивидуальные и блокированные жилые дома.

Принцип «Оставайся в районе» наиболее эффективно был реализован на примере жилых районов, расположенных в 2-7 км от Минска («Новая Боровая», «Пирс», «Зеленая гавань») за счет следующих решений:

- программируемые сервисы на 1 этаже жилых домов и в радиусе пешеходной доступности не более 15 минут;

- планировочные решения квартир с наличием хобби-комнат, террас, лоджий, что позволяет осуществлять трудовую деятельность, учебу, отдых на свежем воздухе, не выходя за пределы квартиры;

- сценарии передвижения с преобладанием пешеходного и велосипедного;

- открытые приватные пространства с размещением в них детских игровых и тренажерных площадок, зон для отдыха и работы на свежем воздухе с возможностью обеспечения социального дистанцирования и уединения (рис. 1).
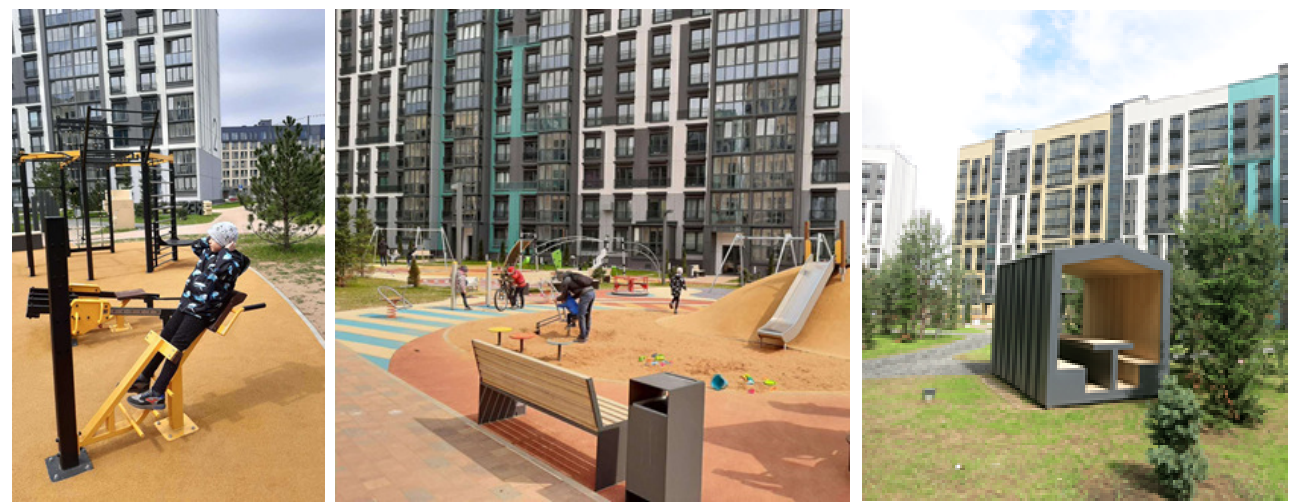

Рис. 1. Организация открытых пространств внутри жилых кварталов. Жилой район «Новая Боровая»

Миграция городского населения из городов с началом пандемии стала возможной, в том числе, благодаря наличию у значительной части жителей крупных городов «резервного» жилья в виде дачных домиков с небольшими участками (как правило, $400 \div 600 \mathrm{~m}^{2}$ ) в радиусе 10-20 км от города. Данная тенденция определила начало активного развития дачных поселков и переформатирования жилья из сезонного в круглогодичное использование.

Бум создания садовых товариществ и дачного строительства в Беларуси наблюдался в конце 70-ых - начале 90-ых годов XX века. Однако строительство в этот период проводилось с определенными ограничениями, в частности по площади застройки участка, 
по высоте жилого дома, по размещению хозяйственных построек на участке и др. Кроме того, дефицит качественных строительных и отделочных материалов, отсутствие или сезонность работы систем водо- и газоснабжения, канализации, отопления позволяли проживать на дачах исключительно в летний период и в выходные дни.

В настоящее время в Беларуси насчитывается более 4700 садовых товариществ и дачных кооперативов, в основном в Минской области (30\%) частично, застроенные жилыми домами с возможностью их адаптации к круглогодичному проживанию.

На примере садового товарищества «Узборье», расположенного в 15 км от г. Минска показана тенденция увеличения круглогодичного использования дач с 38 домовладений (12\% от общего количества) в 2018 году до 68 домовладений (25\% от общего количества) в 2021 году (по состоянию на 01.06.2021 г.). Прогнозируемое количество до конца 2021 года - не менее $40 \%$ (рис. 2).


Рис. 2. Садовое товарищество «Узборье». Минский район.
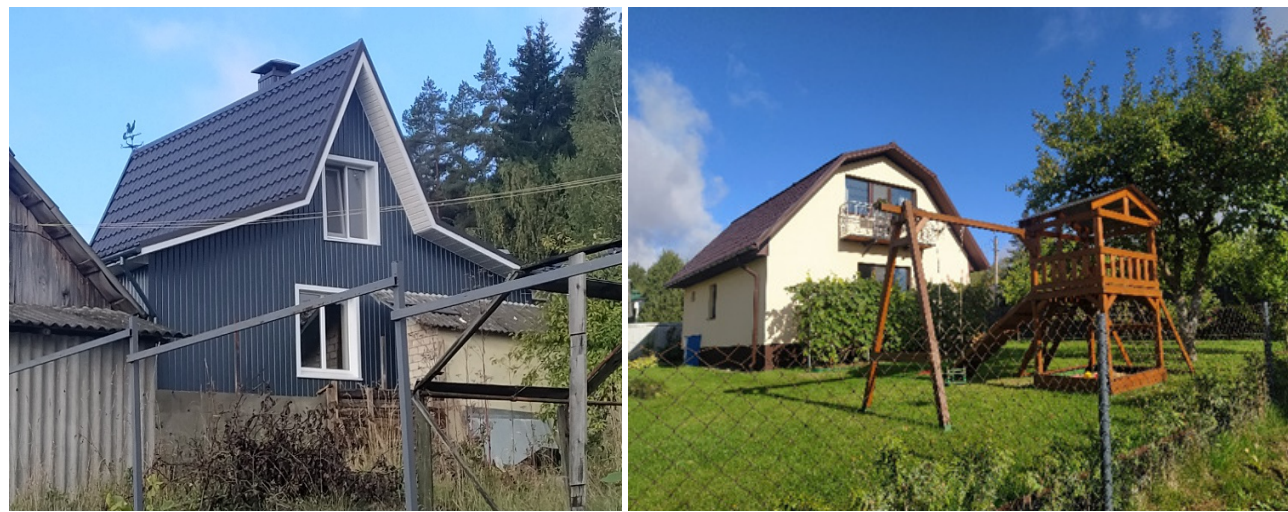

Рис. 3. Садовое товарищество «Узборье». Примеры строительства жилых домов с возможностью круглогодичного использования

Определены следующие направления адаптации жилья к круглогодичному использованию:

- снос ветхих существующих построек и строительство новых жилых домов (рис. 3);

- сохранение существующих построек и строительство новых жилых домов на одном участке;

- пристройка новых объемов к существующим жилым домам с размещением в них жилых помещений, кухонь и санитарных узлов, оборудованных современными системами водоснабжения и канализации, электроснабжения, газоснабжения (рис. 4);

- пристройка веранд и террас. 


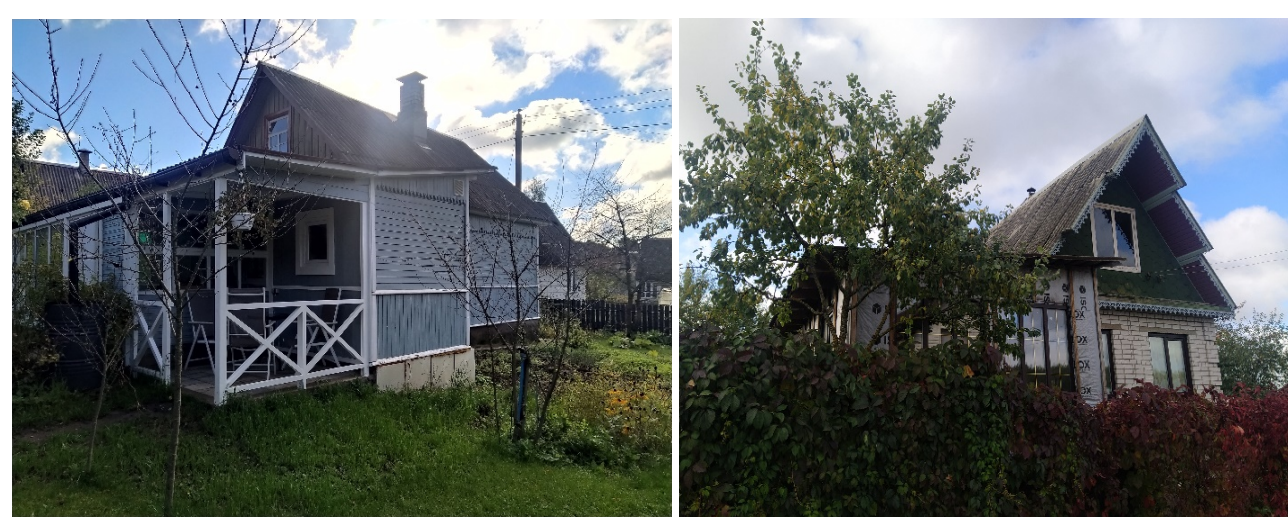

Рис. 4. Садовое товарищество «Узборье». Примеры пристройки новых объемов к существующим домам с возможностью круглогодичного использования ( в процессе строительства)

До недавнего времени создание доступности с учетом принципов универсального дизайна в Беларуси реализовывалось исключительно на уровне городских поселений. Тенденции организации жилой среды в условиях пандемии показали, что доступность должна быть обеспечена на всех уровнях и не может быть создана только в условиях крупных городов, где сосредоточены ресурсы и возможности. Необходимо рассмотрение приемов обеспечения доступности и для граждан, проживающих в отдаленной от социальной инфраструктуры сельской местности, в дачных поселках, что изначально отвечает более высоким стандартам безопасности проживания человека.

Опыт самоизоляции, коллективная память, дезурбанизация, кроме адаптации жилья, требуют децентрализации объектов обслуживания населения с качественным уровнем сервиса, развития малого и среднего бизнеса в регионах.

\section{4. Выводы}

Анализируя ситуацию последних двух лет с позиций эпидемических, социальных и экономических рисков авторы пришли к выводу, что косметическими ситуативными мерами решить возникающие задачи невозможно и существует абсолютная актуальность в рассмотрении и предложении различных форм и способов организации жилой среды и жизнедеятельности человека как нивелирующих эпидемические риски, так и способствующих поддержанию физического, психического и социального благополучия.

\section{Литература}

[1] Zborovskij K.E., Lazovskaya N.A., Universal'nyj dizajn v strategii ustojchivogo razvitiya gosudarstva. Arhitektura i stroitel'stvo 2017, № 1, S. 23-25.

[2] Belarus' v cifrah: statisticheskij spravochnik. Nacional'nyj statisticheskij komitet Respubliki Belarus', Minsk 2018.

[3] Lazovskaya N.A., Universalnyiy dizayn otkryityih prostranstv, zdaniy i sooruzheniy. Minsk 2016.

\section{Evolution of the determinants of universal design in the context of the modern world}

\section{ABSTRACT:}

The article examines conceptual aspects of changing determinants of universal design in response to pandemics or other challenges faced today by the increasingly urbanized humanity. The authors review alternative trends in arrangement of living environment and human activity which help alleviate risks posed 
by the modern challenges of civilization, as well as the creation of enabling conditions for complete physical, mental and social well-being.

\section{KEYWORDS:}

universal design; living environment; pandemic

\section{Ewolucja determinant projektowania uniwersalnego w obliczu nowych wyzwań współczesnego świata}

\section{STRESZCZENIE:}

Artykuł poświęcony jest zagadnieniom zmiany determinant projektowania uniwersalnego pod wpływem pandemii oraz innych wyzwań dla współczesnej ludzkości, skoncentrowanej w miejskich warunkach życia. Autorzy rozważają alternatywne metody organizacji środowiska i życia człowieka, które pozwalają niwelować zagrożenia wyznaczane przez współczesne wyzwania cywilizacyjne. Analizują także warunki zapewnienia pełnego dobrostanu fizycznego, psychicznego i społecznego człowieka.

\section{SŁOWA KLUCZOWE:}

projektowanie uniwersalne; środowisko życia; pandemia 